A draft for the scientific programme of the first International Congress for Automatic Control, which is to be held in Moscow during June 25-July 5, 1960, was submitted by the vice-president of the Federation, Prof. A. M. Letov, Moscow, and was approved by the Executive Council. Further information can be obtained from the Secretariat of the International Federation of Automatic Control, c/o Verein Deutscher Ingenieure, 79 Prinz Georg Strasse, Düsseldorf.

\section{Royal Society of South Africa}

At a recent meeting of the Royal Society of South Africa the following were elected as officers and members of Council for 1958 : President, Prof. E. Newbery ; Hon. General Secretary, W. J. Talbot; Hon. Treasurer, N. Sapeika; Hon. Acting Editor of the Transactions, A. M. Talbot; Hon. Librarian, J. H. Day ; Members of Council, A. J. H. Goodwin, S. H. Haughton, F. G. Holliman, R. F. Lawrence, W. J. Lütjeharms, S. M. Naudé, R. H. Stoy, C. L. Wicht, M. Wilson.

\section{University News :}

Cambridge

Tre Calouste Gulbenkian Foundation, Lisbon, has offered $£ 50,000$ for the proposed new Churchill College (see p. 1359 of this issue of Nature), to endow three Gulbenkian Studentships at the College for graduates of universities outside the United Kingdom. It is proposed that two of the studentships should be tenable for three years undergraduate or postgraduate study at the College, and one should be a senior studentship tenable for one year's postdoctoral research.

London

Prof. C. A. Rogers, Mason professor of pure mathematics in the University of Birmingham, has been appointed to the Astor chair of mathematics, tenable at University College. For a note on Prof. Rogers's work soe Nature $(174,953 ;$ 1954). He succeeds Prof. H. Davenport, who is going to the Rouse Ball chair in Cambridge (see Nature, 181, 528 ; 1958).

Oxford

FURTHER gifts towards the cost of the proposed new College at Oxford--which is intended to replace St. Catherine's Society and to accommodate 400 students, of whom up to half would be scientists, mathematicians and engineers--have recently been announced. The Mullard Company has offered $£ 50,000$ payable over ten years, and the Shell Petroleum Company has offered $\mathfrak{£ 2 5 , 0 0 0}$ payable over seven years towards the general funds of the College, with an additional $£ 2,500$ payable over the same period for the College library.

The Gulbenkian Foundation, Lisbon, has offered $£ 42,000$ to be used for restoring the fabric of the Old Bodleian Library, as part of the University's current campaign for the preservation of its historic buildings.

\section{Announcements}

H.M. King Bafdouin, King of the Belgians, and H.R.H. Charlotte, Grand Duchess of Luxembourg, have graciously accepted honorary membership of the Iron and Steel Institute. They are joint patrons of the Institute's special meeting in Belgium and Luxembourg, which is being held during June 17-28 in conjunction with the Journées Internationales de
Siderurgie, organized in connexion with the Brussels Exhibition.

Mr. T. A. Rogers has been elected president of the Institution of Mining Engineers for the year 1959-60, and will succeed Mr. H. A. Longden at the annual general meeting of the Institution to be held in London next January. Mr. Rogers has recently been appointed H.M. chief inspector of mines and quarries from June 1, in succession to Sir Harold Roberts.

Prof. J. T. ThiJsse, professor of theoretical and experimental hydraulics in the Technical University of Delft, director of the Hydraulic Laboratory in Delft, and consultant to the Netherlands Government in all major water problems, has been awarded the William Bowie Medal of the American Geophysical Union.

THE Royal Society has made the following appointments : Dr. P. M. B. Walker, of the Biophysics Research Unit (Medical Research Council), King's College, London, to the Royal Society Research Fellowship, to work in the Department of Zoology, University of Edinburgh, on the quantitative study of the chemical control mechanisms operating during growth and division; and Mr. N. Tebble, of the British Museum (Natural History), to a John Murray travelling studentship for 1958 to study the Atlantic and Pacific coast Polychæta in the United States.

The Rerry Lectures for 1958, entitled "The Individual and the Universe", will be given by Prof. A. C. B. Lovell, professor of radio astronomy in the University of Manchester and director of the Jodrell Bank Experimental Station. Prof. Lovell will describe the universe as it is revealed by contemporary astronomical techniques and relate the findings of science to religious and philosophical views on the individual's place in the universe. The lectures will be broadcast in the B.B.C. Home Service on successive Sunday evenings at 9.15 p.m., beginning on November 9 .

THE Gulbenkian Foundation has offered to provide $£ 30,000$ to convert Fort Jesus, Mombasa, into a museum of East African history and archæology under the care of the Royal National Parks of Kenya. The building, which has been used as a prison, is a fine example of Portuguese colonial military architecture, and is substantially that built by Matheus Mendes de Vasconcellos in 1594 and restored by Francisco Seixas Cabreira in 1634.

ThE Institution of Electrical Engineers is holding an International Convention on Microwave Valves during May 19-23 at the Institution, Savoy Place, London, W.C.2. An exhibition of apparatus will take place concurrently. Further information can be obtained from the Secretary of the Institution at the above address.

A symposium on "Salinity Problems in Arid Zones", organized jointly by Unesco and the Iranian government, is to be held at the University of Teheran, Iran, next September. The title and an abstract of not more than $\mathbf{2 5 0}$ words of each proposed paper should reach the Natural Science Department, Unesco, before June 1. Complete text of all submitted papers is required by Unesco by or before August 1. Final papers should contain a maximum of 5,000 words as well as the necessary data, diagrams and tables. 